\title{
PENGARUH TINGKAT INFLASI, SUKU BUNGA BI, DAN NILAI TUKAR RUPIAH TERHADAP IHSG
}

\author{
Desi Ratjaya Ningsih ${ }^{1}$, Nur Aida Arifah Tara ${ }^{2}$, Muhdin $^{3}$ \\ ${ }^{1}$ Faculty of Economics and Business, University of Mataram, Indonesia. \\ E-mail: ratjayadesi@gmail.com \\ ${ }^{23}$ Faculty of Economics and Business, University of Mataram, Indonesia.
}

\begin{tabular}{|c|c|}
\hline ARTICLE INFO & ABSTRACT \\
\hline 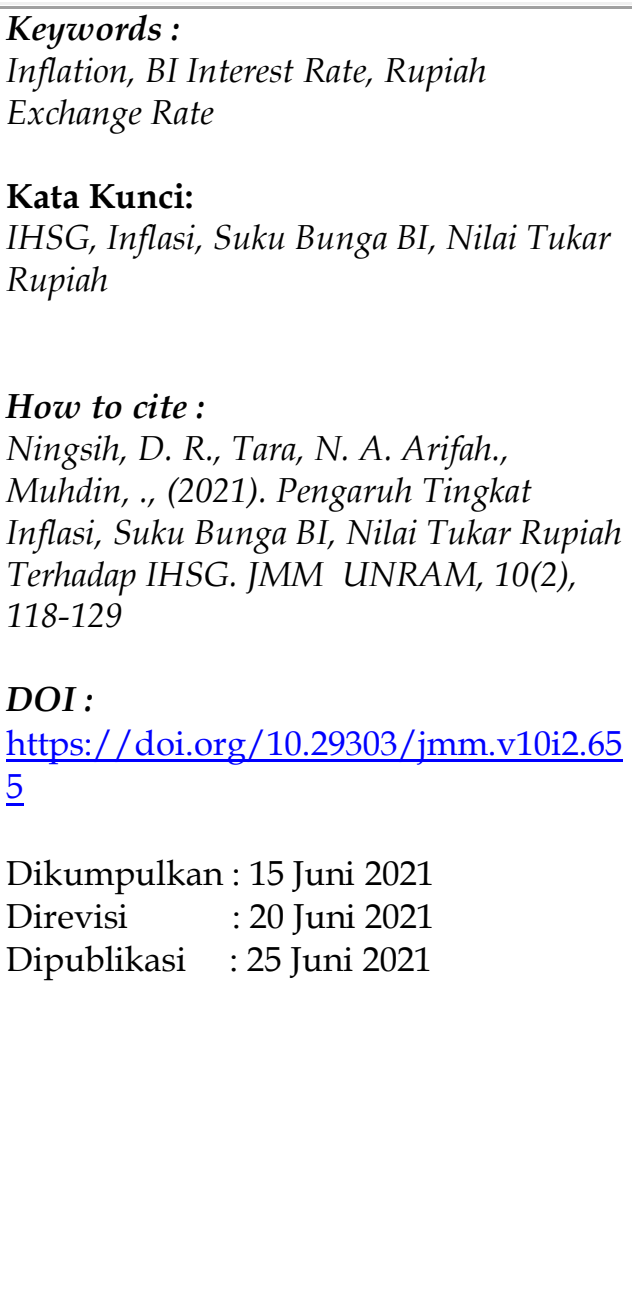 & $\begin{array}{l}\text { The Composite Stock Price Index (IHSG) is a } \\
\text { description of information regarding the movements of } \\
\text { all stock prices that affect capital market conditions } \\
\text { and produce a trend. There are three factors that } \\
\text { mainly influence the IHSG, namely inflation, BI } \\
\text { interest rates, and the rupiah exchange rate. The } \\
\text { purpose of this study was to examine the relationship } \\
\text { between inflation, BI interest rates, rupiah exchange } \\
\text { rate and the IHSG in the period of 2016-2020. The } \\
\text { method in this research used quantitative methods. } \\
\text { The results showed that inflation and BI interest rates } \\
\text { have a negative and insignificant effect on the IHSG, } \\
\text { while the Rupiah exchange rate has a significant } \\
\text { negative effect on the IHSG. } \\
\text { Indeks Harga Saham Gabungan (IHSG) adalah } \\
\text { gambaran informasi mengenai pergerakan } \\
\text { seluruh harga saham yang berpengaruh terhadap } \\
\text { kondisi pasar modal dan menghasilkan suatu } \\
\text { trend. Ada tiga faktor yang secara garis besar } \\
\text { mempengaruhi IHSG yaitu Inflasi, Suku Bunga } \\
\text { BI, dan Nilai Tukar Rupiah. Tujuan penelitian ini } \\
\text { adalah untuk menguji pengaruh variabel inflasi, } \\
\text { suku bunga BI, dan nilai tukar rupiah terhadap } \\
\text { IHSG pada periode 2016-2020. Metode dalam } \\
\text { penelitian ini menggunakan metode kuantitatif. } \\
\text { Hasil penelitian yang didapatkan adalah inflasi } \\
\text { dan suku bunga BI memiliki pengaruh negatif } \\
\text { tidak signifikan terhadap IHSG, sementara nilai } \\
\text { tukar rupiah memiliki pengaruh negatif } \\
\text { signifikan terhadap IHSG. }\end{array}$ \\
\hline & $\begin{array}{l}\text { Copyright } @ 2021 \text { Desi Ratjaya Ningsih, Nur } \\
\text { Aida Arifah Tara, Muhdin. All rights reserved. }\end{array}$ \\
\hline
\end{tabular}




\section{PENDAHULUAN}

Secara umum pasar modal diartikan sebagai media bagi penjual (emiten) dan investor (pembeli) dalam rangka melakukan suatu transaksi untuk memperoleh modal. Investor memiliki harapan untuk mendapatkan suatu keuntungan kedepannya (Kasmir, 2012). Pasar modal diharapkan menjadi suatu alternatif penghimpun dana selain sistem perbankan, dan peningkatan maupun penurunan pasar modal dapat terlihat dari pergerakan naik turunnya harga-harga saham yang tercatat dan tercermin pada Indeks Harga Saham Gabungan (IHSG). IHSG adalah angka indeks yang dijadikan sebagai pembanding suatu peristiwa yang berupa perubahan harga saham dari waktu ke waktu yang telah dirangkap dan digali sehingga menghasilkan suatu peluang (Jogiyanto, 2008). Investor dapat menggunakan IHSG sebagai acuan di pasar modal untuk pengembangan keputusan dalam berinvestasi.

Tabel 1. Perkembangan Indeks Harga Saham Gabungan (IHSG) Periode 2016-2020

\begin{tabular}{|c|c|c|}
\hline Tahun & IHSG & Perkembangan IHSG (\%) \\
\hline 2016 & $5.323,81$ & - \\
\hline 2017 & $5.785,12$ & $7,97 \%$ \\
\hline 2018 & $6.098,58$ & $5,14 \%$ \\
\hline 2019 & $6.324,66$ & $3,57 \%$ \\
\hline 2020 & $5.204,66$ & $-21,52 \%$ \\
\hline
\end{tabular}

Sumber : Finance.yahoo.com

Tabel 1 menunjukkan data perkembangan indeks harga saham gabungan (IHSG) yang dilihat dari rata-rata tahunan dari tahun 2016 sampai 2020. Perkembangan IHSG dari tahun 2017 hingga 2019 mengalami kenaikan sekitar 8,53 dan mengalami penurunan pada tahun 2020 sebesar $-21,52 \%$. Penurunan IHSG secara signifikan terjadi di tahun 2020, dimana IHSG menyentuh level terendahnya akibat sentimen negatif yang ditimbulkan oleh wabah virus COVID-19. Penurunan yang sangat tajam terjadi pada akhir bulan Maret di mana pada bulan ini IHSG terjun ke level terendahnya di 3.937 atau turun minus 37,5\% dibandingkan dengan penutupan perdagangan tahun 2019 dan hingga November 2020 belum mampu kembali ke posisi semula pada 6.000an.

Secara umum, peningkatan dan penurunan indeks saham dapat dipengaruhi oleh beberapa faktor yaitu keadaan ekonomi global, perubahan tingkat suku bunga acuan, kestabilan politik suatu negara, tingkat harga ekonomi dunia dan lain-lain. Akan tetapi ada tiga faktor utama yang dapat mempengaruhi terjadinya peningkatan maupun penurunan IHSG yaitu tingkat inflasi, suku bunga BI, dan nilai tukar rupiah.

Inflasi yaitu suatu peristiwa terjadinya kenaikan harga barang maupun jasa secara umum yang berlangsung secara terus menerus yang berakibat negatif pada perekonomian suatu negara, karena inflasi diartikan sebagai suatu peristiwa terjadinya penurunan daya beli masyarakat dan terjadinya peningkatan jumlah uang beredar. Tingginya tingkat inflasi memberikan suatu sinyal negatif kepada investor yang akan menanamkan modalnya pada pasar modal terkhusus pada pasar saham. Peningkatan inflasi memberikan sinyal pada investor untuk lebih berhati-hati sebelum menetapkan dan memulai kesepakatan (transaksinya), dan hal ini akan memberikan suatu kecenderungan bagi investor untuk menunggu keadaan perekonomian yang lebih kondusif guna meminimalisir risiko yang mungkin dapat diakibatkan dari tingginya tingkat inflasi tersebut, sehingga hal ini akan mengikat persetujuan harga saham yang pada akhirnya akan berdampak pada terjadinya pergeseran indeks harga saham di bursa efek yang cenderung akan mengalami penurunan (Wismantara \& Darmayanti, 2017; Kharisma, 2018; Harsono \& Worokinasih, 2018; Nuraini, 2018). 
Bank Indonesia menetapkan suku bunga pinjaman maupun simpanan yang dijadikan sebagai acuan bagi bank maupun lembaga-lembaga keuangan lainnya di seluruh indonesai yang dinamakan sebagai suku bunga BI. Suku bunga dapat mempengaruhi terjadinya perubahan harga saham pada bursa efek.Suku bunga yang mengalami peningkatan dapat menahan keinginan investor untuk berinvestasi pada saham yang berakibat pada terjadinya kecenderungan investor akan menyimpan dananya pada obligasi yang memberikan keuntungan yang tetap serta risiko yang minim. Hal tersebut mengakibatkan investasi di bursa saham akan semakin turun, karena tingkat suku bunga memberikan signal negatif bagi harga saham yang pada akhirnya berakibat pada melemahnya IHSG. Dengan demikian terjadinya peningkatan suku bunga BI akan mengakibatkan penurunan pada IHSG yang bisa diartikan bahwa pengaruh suku bunga BI negatif pada IHSG (Handayani, 2015; Taufiq \& Kefi, 2016); Harsono \& Worokinasih, 2018).

Nilai tukar merupakan faktor makro ekonomi lainnya yang dapat menyebabkanterjadinya peningkatan maupun penurunan harga saham.Kurs atau nilai tukar merupakan suatu perbandingan nilai mata uang suau negara terhadap nilai mata uang negara lain atau diartikan sebagai harga satu unit mata uang negara lain terhadap mata uang domestik. Nilai tukar juga dapat diartikan sebagai diperlukannya banyak rupiah untuk mendapatkan satu komponen mata uang asing (USD). Adanya perbandingan nilai atau harga diantara kedua mata uang dihasilkan dari adanya pertukaran dua mata uang yang berbeda.

Perusahaan-perusahaan di Indonesia sangat memperhatikan informasi terkait nilai tukar rupiah terhadap US Dollar (USD) dikarenakan secara umum US Dollar banyak dipergunakan oleh perusahaan dalam melakukan transaksi (pembayaran) bahan produksi maupun transaksi bisnis lainnya. Terdepresiasinya nilai tukar rupiah karena mata uang asing yaitu dollar (USD) akan mengakibatkan kenaikan terhadap harga bahan baku karena untuk membeli bahan baku diluar negeri mata uang rupiah yang dikeluarkan lebih banyak untuk membeli atau mendapatkan dollar (USD). Terjadinya penurunan keuntungan perusahaan pada saat biaya produksi mengalami peningkatan mengirimkan sinyal negatif bagi penanam modal (investor)perihal melakukan aksi jual terhadap saham-saham yang dimilikinya, yang mengakibatkan terjadinya pergerakan (penurunan) terhadap IHSG. Hal ini dapat diartikan bahwa nilai tukar rupiah yang mengalami depresiasi terhadap USD akan mengakibatkan terjadinya penurunan terhadap IHSG, yang dimana hal ini dapat dikatakan bahwa adanya pengaruh negatif dari nilai tukar terhadap IHSG (Anggoro, 2011; Kewal , 2012 ; Handayani, 2015; Nuraini, 2018; Kharisma, 2018; Harsono \& Worokinasih, 2018; Supriandi, 2019).

Inflasi, suku bunga, dan nilai tukar merupakan faktor makroekonomi yang telah dijelaskan dapat memberikan pengaruh positif maupun negatif terhadap pergerakan Indeks Harga Saham Gabungan (IHSG). Permintaan dan penawaran investor di pasar modal akan mempengaruhi pergerakan IHSG. Tetapi terdapat perbedaan hasil penelitian terdahulu, maka akan dilakukan pengujian kembali dengan penggembangan tahun penelitian terhadap ketiga variabel utama, yaitu tingkat inflasi, suku bunga BI, dan nilai tukar rupiah yang mempengaruhi IHSG di Bursa Efek Indonesia pada periode 2016-2020. 


\section{KAJIAN PUSTAKA}

\subsection{Investasi}

Suatu bentuk penundaan konsumsi saat ini untuk mendapatkan konsumsi di masa mendatang, dimana adanya unsur risiko ketidakpastian yang terkandung didalamnya yang membutuhkan kompensasi atas penundaan tersebut disebut sebagai investasi (Martalena \& Melinda, 2011). Investasi dapat jugadi definisikan sebagai suatu pengorbanan berdasarkan sejumlah dana atau sumber daya lainnya yang dilakukan pada saat ini dengan harapan akan memperoleh profit di masa berikutnya atau yang akan datang (Tandelilin, 2010).

\subsection{Pasar Modal}

Secara umum pasar modal diartikan sebagai suatu media bagi penjual (emiten) dan pembeli (investor) dalam melakukan transaksi untuk memperoleh modal. Investor (orang yang akan menanamkan modalnya) memiliki harapan untuk mendapatkan suatu keuntungan di masa mendatang (Kasmir, 2012). Pasar untuk berbagai instrumen keuangan yang diperjualbelikan seperti ekuiti (saham), surat utang (obligasi) maupun reksa dana merupakan pasar modal. Pasar modal memiliki motif utama sebagai sarana pendanaan untuk emiten (perusahaan) yang membutuhkan dana atau modal untuk meningkatkan usahanya dengan cara menjual sahamnya kepada investor (pemilik dana). Peningkatan (bullish) maupun penurunan (bearish)dari pergerakan pasar modal dapat dilihat dari naik turunnya harga-hargasaham yang tercatat dan tercermin melalui suatu pergerakan indeks.

\subsection{Indeks Harga Saham Gabungan}

Investor dapat mengukur kinerja gabungan seluruh saham yang tercatat dan tercermin di Bursa Efek Indonesia dengan ditetapkannya indeks pasar saham yang merupakan salah satu Indeks Harga Saham Gabungan (IHSG) atau biasa disebut dengan Composite Share Price Index. Investor dapat melihat adanya kecenderungan harga saham yang sedang naik, stabil, maupun menurun dari pergerakan indeks.

Bursa saham Indonesia dalam penelitian ini diwakili oleh IHSG dikarenakan indeks tersebut telah mendeskripsikan pasar modal Indonesia secara keseluruhan dan mempersentasikan atau menjabarkan pergerakan bursa saham di Indonesia. Berdasarkan closing price (harga penutupan) yang disediakan pada hari tersebut dapat terlihat pergerakan harga saham. Indikator penting bagi para investor dalam menentukan keputusan untuk menjual, menahan maupun membeli suatu atau beberapa saham salah satunya dapat dilihat dari pergerakan indeks. Berdasarkan definisi diatas, IHSG merupakan parameter yang menunjukkan pergerakan harga saham, dan sebagai indikator suatu trend pasar indeks dimanfaatkan sebagai alat untuk mengukur kinerja kerja saham yang tercatat di suatu bursa efek dan dapat dipergunakan sebagai pembanding antara kegiatan yang sama dalam dua waktu yang berbeda (Jogiyanto, 2008).

\subsection{Inflasi}

Inflasi merupakan suatu pristiwa terjadinya kenaikan harga barang maupun jasa secara umum yang berlangsung secara terus menerus yang berakibat negatif pada perekonomian suatu negara, karena inflasi diartikan sebagai suatu peristiwa terjadinya penurunan daya beli masyarakat, terjadinya peningkatan jumlah uang beredar dan nilai mata uang mengalami pelemahan. Kondisi ekonomi secara menyeluruh akan semakin memburuk dan mengguncang tatanan stabilitas politik dari adanya inflasi yang terjadi secara terus menerus (Fahmi, 2012). 
Suatu peristiwa terjadinya kenaikan barang dan jasa secara umum dan terus menerus yang berakibat negatif terhadap perekonomian suatu negara disebut inflasi, karena inflasi diartikan sebagai terjadinya penurunan daya beli masyarakat dan meningkatnya jumlah uang beredar. Secara relatif meningkatnya inflasi akan memberikan sinyal negatif untuk penanam modal (investor) di pasar modal (Wismantara \& Darmayanti, 2017; Kharisma, 2018; Harsono \& Worokinasih, 2018; Nuraini, 2018). Tingginya tingkat inflasi akan membuat investor lebih berhati-hati dalam menentukan dan memulai transaksinya, yang mengakibatkan penanam modal akan memiliki kecenderungan untuk menunggu situasi perekonomian yang kondusif guna menghindari atau meminimalisir risiko yang mungkin akan ditimbulkan dari tingginya tingkat inflasi tersebut dan tentunya hal ini akan mempengaruhi penawaran harga saham yang akan berdampak terhadap pergerakan indeks harga saham yang ada di BEI yang cenderung akan mengalami penurunan.

H1 : Inflasi berpengaruh negatif terhadap Indeks Harga Saham Gabungan (IHSG)

\subsection{Suku Bunga}

Suatu tingkat, harga, nilai maupun keuntungan yang dibagikan untuk investor dari pemakaian (implementasi) dana investasi atas dasar perhitungan nilai ekonomis dalam jangka waktu tertentu disebut suku bunga. Penetapan suku bunga melalui rapat anggota dewan gubernur dengan mempertimbangkan kodisi perekonomian Indonesia dan situasi perekonomian global pada umumnya dilakukan setiap bulan.

Suku bunga pinjaman maupun simpanan bagi bank dan lembaga-lembaga keuangan di seluruh Indonesia mengacu pada tingkat suku bunga yang ditetapkan oleh BI (Bank Indonesia). Fluktuasi harga saham di bursa efek juga dapat dipengaruhi oleh suku bunga. Keinginan investor untuk berinvestasi (menanam modalnya) pada saham dapat dipengaruhi oleh adanya peningkatan suku bunga. Apabila terjadi peningkatan suku bunga akan memberikan suatu kecenderungan bagi investor untuk menyimpan (menanamkan) modalnya dalam bentuk obligasi dikarenakan dapat menghasilkan keuntungan yang tetap dengan risiko yang lebih kecil begitu sebaliknya. Hal tersebut mengakibatkan investasi di bursa saham akan semakin turun, karena tingkat suku bunga memberikan signal negatif bagi harga saham yang pada akhirnya berakibat pada melemahnya IHSG (Handayani, 2015; Taufiq \& Kefi, 2016; Harsono \& Worokinasih, 2018). Dengan demikian tingkat suku bunga BI yang mengalami peningkatan akan mengakibatkan penurunan bagi IHSG yang dimana hal ini bisa diartikan adanya pengaruh negatif suku bunga BI mempunyai pengaruh IHSG.

H2 : Suku Bunga BI berpengaruh negatif terhadap Indeks Harga Saham Gabungan (IHSG)

\subsection{Nilai Tukar Rupiah}

Perbandingan harga mata uang suatu negara terhadap negara lainnya disebut nilai tukar. Alat pengukuran untuk menilai harga mata uang domestik terhadap mata uang asing disebut kurs. Nilai tukar mata uang dalam negeri yang mengalami peningkatan disebut apresiasi terhadap mata uang asing, sedangkan pelemahan (penurunan) nilai tukar dalam negeri disebut depresiasi terhadap mata uang asing.

Perbandingan harga atau nilai mata uang antara dua negara disebut kurs valuta asing atau kurs uang asing. Jumlah uang dalam negeri yang dibutuhkan atau diartikan sebagai dibutuhkannya rupiah yang lebih banyak untuk mendapatkan satu unit mata uang asing disebut sebagai kurs valuta asing. Perbandingan nilai atau harga yang dihasilkan dari pertukaran antara dua mata uang yang berbeda dan perbandingan nilai inilah yang dinamakan kurs. Permintaan dan penawaran di pasar atas mata uang dapat 
mempengaruhi nilai tukar.Nilai tukar terbagi menjadi dua menurut para ahli yaitu kurs nominal (nominal exchange rate) dan kurs riil (real exchange rate). Harga relatif mata uang dua negara disebut kurs nominal, sedangkan harga relatif barang-barang antara dua negara disebut kurs rill (Sukirno, 2010).

Melemahnya nilai tukar rupiah terhadap USD akan berdampak negatif terhadap pasar modal khususnya IHSG yang berdampak pada beralihnya investor dari pasar modal ke pasar uang. Hal ini akan mendorong investor untuk melakukan aksi jual terhadap saham-saham yang dimilikinya yang akan mengakibatkan penurunan Indeks Harga Saham Gabungan (IHSG) (Anggoro, 2011; Kewal , 2012 ; Handayani, 2015; Nuraini, 2018; Kharisma, 2018; Harsono \& Worokinasih, 2018; Supriandi, 2019).

H3 : Nilai Tukar Rupiah berpengaruh negatif terhadap Indeks Harga Saham Gabungan (IHSG)

\section{METODE PENELITIAN}

Penelitian ini adalah penelitian asosiatif atau sebab akibat dengan pendekatan kuantitatif. Penelitian asosiatif yang dimaksud dalam pengamatan (penelitian) ini digunakan untuk menguji apakah variabel independen yaitu inflasi, suku bunga BI, dan nilai tukar rupiah berpengaruh terhadap variabel dependen yaitu Indeks Harga Saham Gabungan (IHSG).

Penelitian ini dilakukan dengan cara mengunduh harga saham bulanan perusahaan emiten. Indeks Harga Saham Gabungan (IHSG) dipilih sebagai objek penelitian dengan alasan karena IHSG merupakan indeks gabungan yang nilainya dapat digunakan sebagai alat untuk mengukur kinerja gabungan seluruh saham yang tercatat di Bursa Efek Indonesia (BEI). Waktu atau periode pengamtan dalam dilakukan secara berkala menggunakan data time series selama 5 tahun dengan jumlah data setiap variabel sebanyak 53 selama periode Agustus 2016 sampai Desember 2020.

\section{HASIL DAN PEMBAHASAN}

\subsection{Hasil}

\subsubsection{Deskriptif Statistik Indeks Harga Saham Gabungan (IHSG)}

Tabel 2 menunjukkan perkembangan Indeks Harga Saham Gabungan (IHSG) selama periode Agustus 2016 sampai Desember 2020 yang dimana IHSG berfluktuasi dari Agustus 2016 sampai 2020. Terlihat pada grafik bahwa perkembangan IHSG tertinggi pada bulan Januari 2018 yang memiliki kenaikan sebesar 3,78\% dan perkembangan IHSG terendah pada bulan Maret 2020 dengan harga IHSG sebesar 4.538,93 dibandingkan dengan Februari 2020 sebesar 5.452,70. Perkembangan IHSG mengalami penurunan sebesar -20,13\%, dimana pada bulan Maret diresmikannya Indonesia terpapar COVID-19. Setelah bulan Maret, perkembangan IHSG kembali meningkat atau pasar menunjukkan respon yang positif.

Panel B merupakan data IHSG sebelum dan selama terjadinya COVID 19 yang menunjukkan jumlah sampel pada sebelum terjadinya COVID-19 sebanyak 43 bulan sedangkan selama terjadinya COVID-19 jumlah sampel sebanyak 10 bulan. Terlihat pada tabel bahwa mean atau rata-rata harga saham lebih tinggi sebelum terjadinya COVID-19 dibandingkan selama terjadinya COVID-19. 


\subsubsection{Deskriptif Statistik Inflasi}

Tabel 2 menunjukkan menunjukkan data tingkat inflasi yang menggunakan sampel sebanyak 53 bulan untuk setiap variabel dengan rata-rata (mean) sebesar 3,03\% dengan nilai tengah (median) sebesar 3,18\% dan standar deviasi (SD) sebesar 0,721\%. Terlihat pada panel A untuk data tahunan jumlah sample yang digunakan pada tahun 2016 sebanyak 5 bulan sedangkan bada tahun 2017 sampai 2020 jumlah sampelnya sebanyak 12 bulan. Rata-rata dan nilai tengah untuk data inflasi terbesar pada tahun 2017 sebesar 3,81\% dan 3,77\%. Sedangkan standar deviasi terbesar terdapat pada tahun 2020 sebesar 0,63\% yang dimana semakin besar standar deviasi menunjukkan adanya penyebaran yang besar pula.

Panel B merupakan data inflasi sebelum dan selama terjadinya COVID 19 yang menunjukkan jumlah sampel pada sebelum terjadinya COVID-19 sebanyak 43 bulan sedangkan selama terjadinya COVID-19 jumlah sampel sebanyak 10 bulan. Terlihat pada tabel bahwa mean atau rata-rata inflasi lebih tinggi sebelum terjadinya COVID-19 dibandingkan selama terjadinya COVID-19.

\subsubsection{Deskriptif Statistik Suku Bunga BI}

Tabel 2 menunjukkan menunjukkan data suku bunga BI yang menggunakan sampel sebanyak 53 bulan untuk setiap variabel dengan rata-rata (mean) sebesar 4,89\% dengan nilai tengah (median) sebesar 4,75\% dan standar deviasi (SD) sebesar 0,68\%. Terlihat pada panel A untuk data tahunan jumlah sample yang digunakan pada tahun 2016 sebanyak 5 bulan sedangkan bada tahun 2017 sampai 2020 jumlah sampelnya sebanyak 12 bulan. Mean dan median untuk data suku bunga BI terbesar pada tahun 2019 sebesar 5,63\% dan 5,88\%. Sedangkan standar deviasi terbesar terdapat pada tahun 2018 sebesar 0,72\% yang dimana semakin besar standar deviasi menunjukkan adanya penyebaran yang besar pula.

Panel B merupakan data suku bunga BI sebelum dan selama terjadinya COVID 19 yang menunjukkan jumlah sampel pada sebelum terjadinya COVID-19 sebanyak 43 bulan sedangkan selama terjadinya COVID-19 jumlah sampelnya sebanyak 10 bulan. Terlihat pada tabel bahwa mean atau rata-rata suku bunga BI lebih tinggi sebelum terjadinya COVID-19 dibandingkan selama terjadinya COVID-19.

\subsubsection{Deskriptif Statistik Nilai Tukar Rupiah}

Tabel 2 menunjukkan menunjukkan data nilai tukar rupiah yang menggunakan sampel sebanyak 53 bulan untuk setiap variabel dengan rata-rata (mean) sebesar Rp. 14.044 dengan nilai tengah (median) sebesar Rp. 14.044 dan standar deviasi (SD) sebesar 2.027,88. Terlihat pada panel A untuk data tahunan jumlah sample yang digunakan pada tahun 2016 sebanyak 5 bulan sedangkan bada tahun 2017 sampai 2020 jumlah sampelnya sebanyak 12 bulan. Mean, media, dan standar deviasi untuk data nilai tukar rupiah terbesar pada tahun 2020 sebesar Rp.14.627, Rp.14.604, dan 681,61.

Panel B merupakan data nilai tukar rupiah sebelum dan selama terjadinya COVID 19 yang menunjukkan jumlah sampel pada sebelum terjadinya COVID-19 sebanyak 43 bulan sedangkan selama terjadinya COVID-19 jumlah sampelnya sebanyak 10 bulan. Terlihat pada tabel bahwa mean atau rata-rata nilai tukar rupiah lebih tinggi sebelum terjadinya COVID-19 dibandingkan selama terjadinya COVID-19. 
Tabel 2. Data Indeks Harga Saham Gabungan (IHSG), Inflasi, Suku Bunga BI dan Nilai Tukar Rupiah Periode 2016 - 2020

\begin{tabular}{|l|c|c|c|c|c|}
\hline \multirow{2}{*}{} & N & IHSG & $\begin{array}{c}\text { Inflasi } \\
(\%)\end{array}$ & $\begin{array}{c}\text { Suku Bunga BI } \\
(\mathbf{\%})\end{array}$ & $\begin{array}{c}\text { Nilai Tukar Rupiah } \\
(\mathbf{R p})\end{array}$ \\
\cline { 3 - 6 } & & Mean & Mean & Mean & Mean \\
\hline Semua Sampel & 53 & $5.803,31$ & $3,03 \%$ & $4,89 \%$ & 14.014 \\
\hline Panel A: Tahun & 5 & $5.323,81$ & $3,15 \%$ & $4,90 \%$ & 13.270 \\
\hline 2016 & 12 & $5.785,12$ & $3,81 \%$ & $4,56 \%$ & 13.398 \\
\hline 2017 & 12 & $6.098,58$ & $3,20 \%$ & $5,10 \%$ & 14.267 \\
\hline 2018 & 12 & $6.324,66$ & $3,03 \%$ & $5,63 \%$ & 14.131 \\
\hline 2019 & 12 & $5.204,66$ & $2,04 \%$ & $4,25 \%$ & 14.627 \\
\hline 2020 & \multicolumn{7}{|l|}{} \\
\hline Panel B: Sebelum dan Selama COVID-19 & \\
\hline Sebelum COVID-19 & 43 & $5.965,40$ & $3,30 \%$ & $5,06 \%$ & 13.856 \\
\hline Selama COVID-19 & 10 & $5.106,31$ & $1,88 \%$ & $4,13 \%$ & 14.770 \\
\hline
\end{tabular}

Sumber : Data diolah 2021

\subsection{Analisis Regresi}

Untuk mengetahui pengaruh inflasi, tingkat suku bunga BI, dan nilai tukar rupiah, dalam pengujiannya menggunakan model regresi sebagai berikut:

Persamaan analisis linier berganda:

$$
\mathrm{Y}=0,002-0,059 \mathrm{X} 1-0,017 \mathrm{X} 2-1.140 \mathrm{X} 3+\mathrm{e}
$$

Tabel 3. Analisis Regresi Linier Berganda

\begin{tabular}{|c|c|c|c|c|}
\hline \multicolumn{5}{|c|}{ Coefficients } \\
\hline \multirow{2}{*}{\multicolumn{2}{|c|}{ Model }} & Unstandardized & $t$ & Sig. \\
\hline & & B & & \\
\hline \multirow{4}{*}{1} & (Constant) & .002 & 341 & .735 \\
\hline & Inflasi (X1) & -.059 & -1.222 & .228 \\
\hline & Suku Bunga BI (X2) & -.017 & -.131 & .896 \\
\hline & Nilai Tukar Rupiah (X3) & -1.140 & -6.944 & .000 \\
\hline
\end{tabular}

Sumber: Data diolah

\subsection{Uji t (Uji Parsial)}

\section{Hasil Pengujian Hipotesis 1}

Berdasarkan Tabel 3 dapat dilihat bahwa tingkat inflasi memiliki nilai t-hitung sebesar -1,222 dan t-tabel ( $a / 2$; n-k-1) atau (0,025; 53-3-1 = 0,025; 49) sebesar 2,009 dengan koefisien tingkat signifikansi sebesar 0,228. Jadi dapat disimpulkan bahwa signifikansi tingkat inflasi 0,228> dari tingkat signifikan yang diterapkan 0,05 dan t-hitung < t-tabel hal ini dapat diartikan bahwa inflasi berpengaruh negatif dan tidak signifikan terhadap Indeks Harga Saham Gabungan (IHSG). Berdasarkan analisis ini maka hipotesis pertama ditolak. 


\subsection{Hasil Pengujian Hipotesis 2}

Berdasarkan Tabel 3 dapat dilihat bahwa suku bunga BI memiliki nilai t-hitung sebesar -0,131 dan t-tabel sebesar 2,009 dengan koefisien tingkat signifikansi lebih besar dibandingkan dengan taraf signifikan yang sudah di terapkan $(0,896>0,05)$ dan t-hitung $<$ t-tabel. Berdasarkan hasil tersebut dapat disimpulkan bahwa suku bunga BI memiliki pengaruh yang negatif dan tidak signifikan terhadap Indeks Harga Saham Gabungan (IHSG). Berdasarkan analisis ini maka hipotesis kedua ditolak.

\subsection{Hasil Pengujian Hipotesis 3}

Berdasarkan Tabel 3 dapat dilihat bahwa nilai tukar rupiah memiliki nilai t-hitung sebesar -6,944 dan t-tabel sebesar 2,009 dengan koefisien tingkat signifikansi lebih kecil dibandingkan dengan taraf signifikan yang sudah di terapkan $(0,00<0,05)$ dan $\mathrm{t}$-hitung $>\mathrm{t}$ tabel. Berdasarkan hasil tersebut dapat disimpulkan bahwa nilai tukar rupiah memiliki pengaruh negatif dan signifikan terhadap Indeks Harga Saham Gabungan (IHSG). Berdasarkan analisis ini maka hipotesis ketiga diterima

\subsection{Uji F (Uji Simultan)}

Tabel 4 diatas terlihat bahwa nilai F-hitung sebesar 17,783> F-tabel (k; n-k) atau (3; $53-3=3 ; 50$ ) sebanyak 2,79 dengan signifikansi 0,000 $<0,05$. Berdasarkan penjabaran diatas dapat ditarik suatu kesimpulan bahwa variabel independen $(X)$ yaitu inflasi, suku bunga BI dan nilai tukar rupiah secara bersama-sama atau simultan berpengaruh terhadap variabel dependen (IHSG).

Tabel 4. Uji F

\begin{tabular}{|c|c|c|c|c|}
\hline \multicolumn{5}{|c|}{ ANOVA $^{a}$} \\
\hline & Model & Df & $\mathrm{F}$ & Sig. \\
\hline \multirow{3}{*}{1} & Regression & 3 & 17.783 & $.000^{\mathrm{b}}$ \\
\hline & Residual & 49 & & \\
\hline & Total & 52 & & \\
\hline \multicolumn{5}{|c|}{ a. Dependent Variable: IHSG } \\
\hline
\end{tabular}

Sumber: Data diolah

\subsection{Analisis Koefisien Determinasi $\left(\mathbf{R}^{2}\right)$}

Hasil output SPPS model summary dapat dilihat besarnya adjusted $\mathrm{R}^{2}$ adalah 0,492 atau 49,2\% variasi IHSG mampu diuraikan oleh variasi dari ketiga variabel independen yang diteliti. Sementarasekitar $(100 \%-49,2 \%=50,8 \%)$ sisanya dijelaskan oleh faktor lain atau variabel lain yang tidak diteliti dalam penelitian ini.

Tabel 5. Analisis Koefisien Determinasi Dengan Melihat Nilai Adjusted R Square

\begin{tabular}{|c|c|c|}
\hline \multicolumn{3}{|c|}{ Model Summary } \\
\hline Model & R Square & Adjusted R Square \\
& & .492 \\
\hline 1 & .521 & .21 . \\
\hline \multicolumn{2}{|c|}{ a. Predictors: (Constant), Inflasi,Suku Bunga BI, dan Nilai Tukar Rupiah } \\
\hline
\end{tabular}

Sumber: Data diolah 


\subsection{Pembahasan}

\subsubsection{Pengaruh Tingkat Inflasi Terhadap Indeks Harga Saham Gabungan (IHSG)}

Pengujian hipotesis (uji t) menghasilkan suatu yang menjelaskan bahwa tingkat inflasi memiliki pengaruh negatif dan tidak signifikan terhadap IHSG di Bursa Efek Indonesia. Dilihat bahwa tingkat inflasi memiliki nilai t hitung sebesar -1,222pada koefisien tingkat signifikansi $0,228>$ dari tingkat signifikansi yang diterapkan $(0,228>0,05)$. Jadi hipotesis pertama yang menyatakan bahwa inflasi berpengaruh negatif terhadap Indeks Harga Saham Gabungan (IHSG) ditolak.

Hasil penelitian yang didapatkan sejalan atau sesuai dengan penelitian yang dilakukan oleh Handayani (2015), serta Harsono dan Worokinasih (2018) yang menyebutkan bahwa inflasi berpengaruh negatif dan tidak signifikan terhadap IHSG di Bursa Efek Indonesia. Jika inflasi mengalami peningkatan sebesar 1\% maka Indeks Harga Saham Gabungan (IHSG) (Y) akan mengalami penurunan sebesar -0,059 dan begitu sebaliknya dengan asumsi variabel independen lainnya di dalam persamaan nilainya tetap.

Inflasi yang tinggi akan menyebabkan daya beli masyarakat menurun karena harga kebutuhan terus meningkat yang mengakibatkan dana atau penghasilan yang akan diinvestasikan khususnya dipasar modal akan ikut mengalami penurunan. Meningkatnya inflasi memberikan sinyal negatif yang menyebabkan investor lebih mewanti-wanti atau berhati-hati sebelum menentukan dan melakukan transaksinya, yang mengakibatkan investor akan lebih cenderung menunggu keadaan perekonomian kondusif agar dapat menghindari risiko-risiko yang mungkin dapat ditimbulkan dari tingginya inflasi. Hal tersebut tentu akan mempengaruhi terjadinya penawaran harga saham yang pada akhirnya akan berdampak terhadap pergerakan indeks harga saham di BEI yang cenderung akan mengalami penurunan.

\subsubsection{Pengaruh Suku Bunga BI Terhadap Indeks Harga Saham Gabungan (IHSG)}

Pengujian hipotesis pada uji $\mathrm{t}$ menyatakan adanya pengaruh negatif dan tidak signifikan dari suku bunga BI terhadap Indeks Harga Saham Gabungan (IHSG). Dilihat bahwa nilai t-hitung sebesar -0,131 dengan koefisien tingkat signifikansi lebih besar dibandingkan dengan taraf signifikan yang sudah di terapkan $(0,896<0,05)$ yang dihasilkan suku bunga BI pada tabel uji hipotesis. Sesuai dengan analisis tersebut hipotesis kedua yang menyatakan bahwa suku bunga BI berpengaruh negatif bagi Indeks Harga Saham Gabungan (IHSG) ditolak.

Hasil penelitian diatas sejalan dengan penelitian yang dilakukan oleh Handayani (2015), Taufiq dan Kefi (2016), serta Harsono dan Worokinasih (2018) yang menyatakan bahwa suku bunga BI memiliki pengaruh negatif terhadap IHSG di Bursa Efek Indonesia. Tingkat suku bunga yang mengalami perubahan dapat mempengaruhi terjadinya pergerakan saham di Indonesia.Jika terdapat penurunan suku bunga bisa mengakibatkan penurunan bagi suku bunga pinjaman maupun suku bunga yang ada di lembaga-lembaga keuangan di Indonesia.Tingginya tingkat suku bunga akan mengakibatkan atau mempengaruhi keinginan seseorang (investor) untuk menanam modalnya (berinvestasi) pada pasar saham dan memberikan suatu kecenderuangan bagi investor untuk lebih memilih menanamkan modalnya dalam bentuk obligasi yang memberikan keuntungan atau return yang tetap dengan risiko yang kecil dan begitu sebaliknya.

\subsubsection{Pengaruh Nilai Tukar Rupiah Terhadap Indeks Harga Saham Gabungan (IHSG)}

Hasil uji hipotesis (uji t) menjelaskan bahwa nilai tukar rupiah memiliki pengaruh negatif dan signifikan terhadap IHSG di Bursa Efek Indonesia. Dilihat dari hasil pengujian didapatkan bahwa nilai tukar rupiah menghasilkan t-hitung sebesar $-6,944$ serta koefisien 
tingkat signifikansi yang lebih kecil dibandingkan dengan taraf signifikan yang sudah di terapkan $(0,00<0,05)$. Sesuai dengan analisis ini maka hipotesis ketiganya diterima yang menyatakan adanya pengaruh negatif dari nilai tukar rupiah terhadap Indeks Harga Saham Gabungan (IHSG). Hal tersebut sejalan dengan penelitian yang dilakukan oleh Anggoro (2011), Kewal (2012), Handayani (2015), Nuraini (2018), Harsono dan Worokinasih (2018), dan Supriandi (2019) menyatakan bahwa nilai tukar rupiah memiliki pengaruh negatif dan signifikan terhadap IHSG.

Umumnya informasi terkait nilai tukar terhadap US Dollar (USD) lebih diperhatikan oleh perusahaan yang ada di Indonesia, dikarenakan USD secara umum dipakai perusahan dalam melakukan pembayaran bahan produksi maupun transaksi bisnis lainnya. Nilai tukar rupiah yang melemah terhadap USD akan berdampak negatif terhadap pasar modal karena investor kemungkinan akan beralih ke pasar uang. Kurs yang terdepresiasi oleh mata uang asing yaitu dollar (USD) akan mengakibatkan kenaikan terhadap harga bahan baku karena untuk membeli bahan baku diluar negeri mata uang rupiah yang dikeluarkan lebih banyak untuk membeli dollar (USD). Terdorongnya investor untuk melakukan aksi jual terhadap saham-saham yang dimilikinya pada saat terjadinya depresiasi nilai tukar rupiah tehadap USD. Jikapara investormelakukan hal tersebut, tentu akan menggerakan atau mendorong terjadinya penurunan Indeks Harga Saham Gabungan (IHSG).

\section{KESIMPULAN}

Indeks Harga Saham Gabungan (IHSG) adalah gambaran informasi mengenai pergerakan seluruh harga saham yang berpengaruh terhadap kondisi pasar modal dan menghasilkan suatu trend. Ada tiga faktor yang secara garis besar mempengaruhi IHSG yaitu Inflasi, Suku Bunga BI, dan Nilai Tukar Rupiah. Hasil penelitian menunjukkan bahwa inflasi dan Suku Bunga BI memiliki pengaruh negatif dan tidak signifikan bagi Indeks Harga Saham Gabungan (IHSG), sedangkan nilai tukar Rupiah memiliki pengaruh negatif dan signifikan terhadap Indeks Harga Saham Gabungan (IHSG). 


\section{DAFTAR PUSTAKA}

Anggoro, T. S. (2011). Pengaruh Inflasi, Kurs, Harga Emas, dan Suku Bunga SBI Terhadap Indeks Harga Saham Gabungan (IHSG) Pada Bursa Efek Indonesia.

Bank Indonesia. 2016-2020. "Inflasi". Diakses 21 November 2020 dari https://www.bi.go.id/id/statistik/indikator/data-inflasi.aspx

Bank Indonesia.2016-2020. "Suku Bunga BI 7-Day Repo Date".Diakses 21 November 2020 dari https://www.bi.go.id/id/statistik/indikator/bi-7day-rr.aspx

Bank Indonesia.2016-2020. "Nilai Tukar Rupiah". Diakses 21 November 2020 dari https://www.bi.go.id/id/statistik/informasi-kurs/transaksi-bi/default.aspx

Fahmi, I. (2012). Pengantar Pasar Modal. Bandung: Alfabeta.

Ghozali. (2013). Aplikasi Analisis Multivariate Dengan Program IBM SPSS 21 Up Date PLS Regresi. Semarang: Badan Penerbit Universitas Diponegoro.

Handayani, F. (2015). Analisis Pengaruh Perubahan Tingkat Suku Bunga, Inflasi, dan Nilai Tukar Terhadap Indeks Harga Saham Gabungan.

Harsono, A. R., \& Worokinasih, S. (2018). Pengaruh Inflasi, Suku Bunga dan Nilai Tukar Rupiah Terhadap Indeks Harga Saham Gabungan. Jurnal Administrasi Bisnis (JAB). Universitas Brawijaya Malang. Vol. 60, No. 2.

Indeks Harga Saham Gabungan. Diakses 21 November 2020 dari https:/ finance.yahoo.com Jogiyanto. (2008). Teori Portofolio dan Analisis Investasi.

Kasmir.(2012). Bank dan Lembaga Keungan Lainnya.PT Rajagrafindo Persada.

Kewal, S. S. (2012).Pengaruh Inflasi, Suku Bunga, Kurs, dan Pertumbuhan PDB Terhadap Indeks Harga Saham Gabungan .Jurnal Sekolah Tinggi Ilmu Ekonomi Musi Palembang. Vol. 8, No. 1.

Kharisma, F. (2018). Pengaruh Tingkat Inflasi, Suku Bunga BI, Kurs Dolar AS (USD) Terhadap Indeks Harga Saham Gabungan Di Bursa Efek Indonesia.

Krisna, A. A., \& Wirawati, N. G. (2013).Pengaruh Inflasi, Nilai Tukar Rupiah, Suku Bunga SBI Pada Indeks Harga Saham Gabungan Di BEI. E-Jurnal Akuntansi Universitas Udayana. Vol 3, No. 2

Martalena,\& Melinda. (2011). Pengantar Pasar Modal.

Nuraini. (2018). Pengarauh Inflasi, Suku Bunga BI, Nilai Tukar, dan Jumlah Uang Beredar Terhadap Indeks Harga Saham Gabungan Di Bursa Efek Indonesia.

Sukirno, Sadono. 2010. Makroekonomi: Teori Pengantar. Edisi Ketiga. Jakarta: Rajawali Pers

Supriandi. (2019). Pengaruh Inflasi, Nilai Tukar (Kurs), dan Suku Bunga SBI Terhadap Indeks Harga Saham Gabungan Di Bursa Efek Indonesia.

Tandelilin, E. (2010). Portofolio dan Investasi Teori dan Aplikasi. Yogyakarta: Kanisius .

Taufiq, M., \& Kefi, B. S. (2015). Pengarauh Inflasi, BI Rate dan Kurs Terhadap Indeks Harga Saham Gabungan.

Wismantara, S. Y., \& Darmayanti, N. P. (2017).Pengaruh Nilai Tukar, Suku Bunga dan Inflasi Terhadap Indeks Harga Saham Gabungan Di Bursa Efek Indonesia. Jurnal Manajemen UNUD. 